\title{
Neotectonics of Boroujerd Area, SW Iran by Index of Active Tectonics
}

\author{
Maryam Omidali' ${ }^{1}$, Mehran Arian1 ${ }^{*}$, Ali Sorbi2 \\ ${ }^{1}$ Department of Geology, Science and Research Branch, Islamic Azad University, Tehran, Iran \\ ${ }^{2}$ Department of Geology, Karaj Branch, Islamic Azad University, Karaj, Iran \\ Email: * mehranarian@yahoo.com
}

Received 14 April 2015; accepted 11 May 2015; published 15 May 2015

Copyright (C) 2015 by authors and Scientific Research Publishing Inc.

This work is licensed under the Creative Commons Attribution International License (CC BY). http://creativecommons.org/licenses/by/4.0/

C) $\underset{\mathrm{EY}}{\mathrm{i}}$ Open Access

\begin{abstract}
Boroujerd area has located in the border zone of Zagros mountain and Sanandaj-Sirjan belt in the southwest Iran. Six geomorphic indices were calculated in the study area. Through averaging these indices we obtain index of active tectonics (Iat). The values of the index were divided into classes to define the degree of active tectonics. Therefore, relative tectonic activity was calculated and their values were classified and analyzed in two groups. Regions were identified as low and moderate levels. In analyzing data and combining them with tectonic setting the results were often associated and justified with regional geology. Our results show that the highest value has located along faulted area, which shows 3 classes of relative tectonic activity (moderate level). Also, other values have located along folded area (low level). Therefore, middle part of study area (sub-basin No. 4) is showing the more active uplifting related to surroundings region (sub-basin No. 1, 2 and 3). In other words, sub-basin No. 4 has got the more active uplifting by quaternary movements of several faults such as Doroud fault.
\end{abstract}

\section{Keywords}

Neotectonics, Geomorohic Index, Boroujerd, Zagros, Iran

\section{Introduction}

The study area is around Boroujerd city in the border zone of Zagros hinterland and Sanandaj-Sirjan belt in the south west Iran (Figure 1). This area is structurally and geographically belonging to Zagros Mountain. Its northeastern margin belongs to Sanandaj-Sirjan zone and its rest belongs to Zagros Mountain. These two zones have no similar geologic history. Sanandaj-Sirjan zone has comprised from some intrusive bodies in this area.

${ }^{*}$ Corresponding author. 


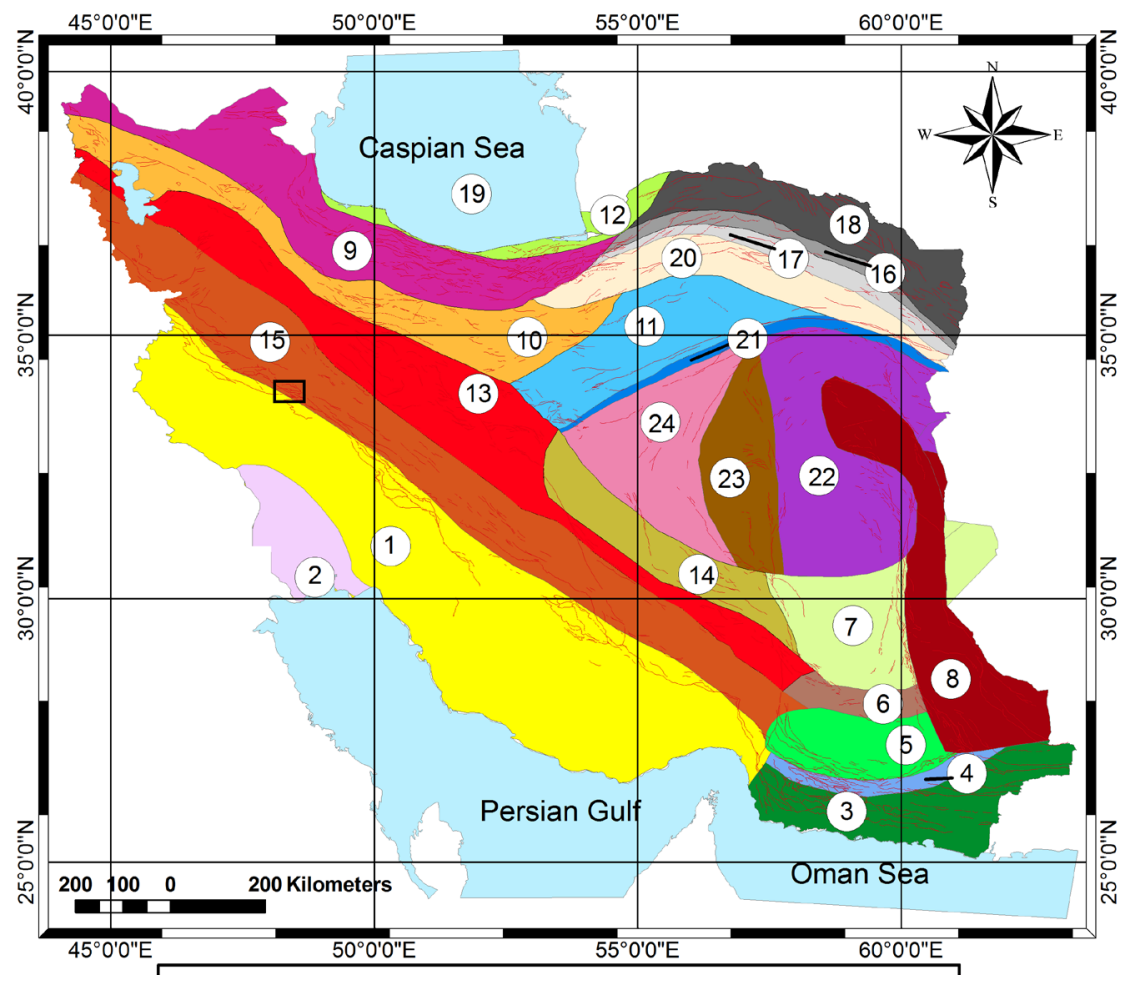

Figure 1. Physiographic-tectonic zoning map of Iran's sedimentary basins Iran modified from [1]. Numbers in this figure are, 1: Zagros-East Taurus hinterland, 2: Persian Gulf-Mesopotamian foreland basin, 3: Makran accretionary prism, 4: Bashagard Mountains, 5: Jazmorian-Mashkel fore arc basin, 6: Shahsavaran-Soltan magmatic arc, 7: South Lut-South Helmand back arc basin, 8: East Iran Mountain belt, 9: West-Central Alborz and lesser Caucasus hinterland, 10: Great Kavir-Nor-thenUr- mieh lake foreland basin, 11: South Great Kavirfold and thrust belt, 12: South Caspian-Black sea foreland basin, 13: UrmiehDokhtar Magmatic Arc, 14: Naien-Kerman retro arc foreland basin, 15: Sanandaj-Sirjanover thrust belts, 16: East Alborz or Binalod hinterland, 17: Torbat-e am-Neyshabour retro arc foreland basin, 18: KopetDagh hinterland, 19: South Caspian remnant basin, 20: Maiamay-Taibad Inverted back arc basin, 21: Khaf-Kavir Plain Magmatic Arc, 22: Lut Plain-Gonabad back arc basin, 23: Tabas hinterland, 24: Yazd-Khour Piggy back basin. The study area is shown in the black rectangle.

The southwestern part is a folded mountain belt in which lies the highest parts of the mountain. The boundary of these two different zones is Silakhor plains covered by alluvium.

These two structural zones have structural, metamorphic, magmatic contrasts so that this province can be divided into two contrasting domains: The north-eastern parts of this area are territories defined by magmatic, thermic, metamorphic features and most of the rock sequences are metamorphic. Pellitic metamorphic rocks constitute low lands while marbles are feature forming. The south-western parts of this area are platform sequences of Paleozoic to Triassic that they are composed of sandstone, limestone. Rock sequences younger than Triassic are limited to Plio-Quaternary conglomerates which are formed as post-orogenic deposit. Dominant structural trends in Zagros are NW-SE in this area. From tectonics view, it contains the over thrust and simple fold belts of Zagros that formed on the northeastern part of Arabian plate's passive margin. Zagros hinterland is external platform (fold and thrust belt) of north margin of Arabian Craton (Figure 1). Vergence of folding in this hinterland is toward south and southwest. But, Sanandaj-Sirjan overthrust belt has been formed by metamorphic rocks of the northeastern part of Arabian plate. Late Cretaceous-Paleogene sequences in this belt have piled up on a wedge top part of Zagros, before regional metamorphism. Recently, pre-Cretaceous deformed and metamorphic rocks have exposed in this province by upthrusting of basement wedges [1]-[3]. In this research, area is divided into 4 sub-basins and the following indices are calculated: stream-gradient index $(S I)$, valley floor width-valley height ratio $(V f)$, and mountain-front sinuosity (Smf), drainage basin asymmetry ( $A f$ ), hypsometric integral (Hi) and drainage basin shape (Bs). We use geomorphic indices of active tectonics, known to be useful in active tectonic studies [4]-[7]; methodology has been previously tested as a valuable tool in different tectonically active areas, namely SW USA [8], the Pacific coast of Costa Rica [9], central Zagros, Iran [10]. 


\section{Materials and Methods}

The calculated geomorphic indices are suitable for assessment of tectonic activity of the study area. The geomorphic indices such as: stream-gradient index $(S I)$, valley floor width-valley height ratio $(V f)$, mountain-front sinuosity $(\mathrm{Sm} f)$, drainage basin asymmetry $(\mathrm{Af})$, hypsometric integral $(\mathrm{Hi})$ and drainage basin shape $(\mathrm{Bs})$ are calculated in Boroujerd area by using of topographic data and DEM (Figure 2). On the other hand, the area was divided to four sub-basins tructural and for each one, indices were calculated, then all of the indices were combined to obtain index of active tectonics (Iat) by new method [11]. Therefore, sub-basins can be compared together. The study area is located between longitudes E48 $30^{\prime}-49^{\circ}$ and latitudes $\mathrm{N} 33^{\circ} 45^{\prime}-34^{\circ}$ in the Louristan province, south west Iran. Based on previous work on the salt diapirism [12]-[21] and neotectonics regime in Iran [22]-[26], Zagros in south Iran is the most active zone [27]-[36]. Then, Alborz [37]-[69] and Central Iran [70]-[82] have been situated in the next orders.

Altitudes in this area reach to $3645 \mathrm{~m}$ on Garin mountain in the western part of Boroujerd, which it have about $2100 \mathrm{~m}$ difference respect to the Silakhore plain in the south eastern part of it. Geomorphologically, the ridges and valleys in the area under study are mainly due to the rocks variations in the lithology and assisted by faults presence in the area that offer varying degrees of resistance to the degradation processes. Topographically, the down faulted. Silakhore plain is quaternary alluvium covered (Figure 3).

\section{Results and Discussion}

To study the indices, there is a formula which we turn to describe each one of indices; It is necessary to have some primary maps to calculate the indices, and the most important of which are: Digital Elevation Model (DEM), the drainage network and the sub-basins map of the Boroujerd area that have been extracted from DEM (Figure 4). DEM extracted from a digitized topographic map (with $10 \mathrm{~m}$ intervals).

\subsection{The Stream-Gradient Index (SL)}

The rivers flowing over rocks and soils of various strengths tend to reach equilibrium with specific longitudinal profiles and hydraulic geometrics [83] [84]. [85] defined the stream-gradient index (SL) to discuss influences of environmental variables on longitudinal stream profiles, and to test whether streams has reached equilibrium. The calculation formula is in this manner:

$$
S L=(\Delta H / \Delta L) L
$$

where $(\Delta H / \Delta L)$ is local slope of the channel segment that is located between two contours and $L$ is the channel length from the division to the midpoint of the channel reaches for which the index is calculated. This index is

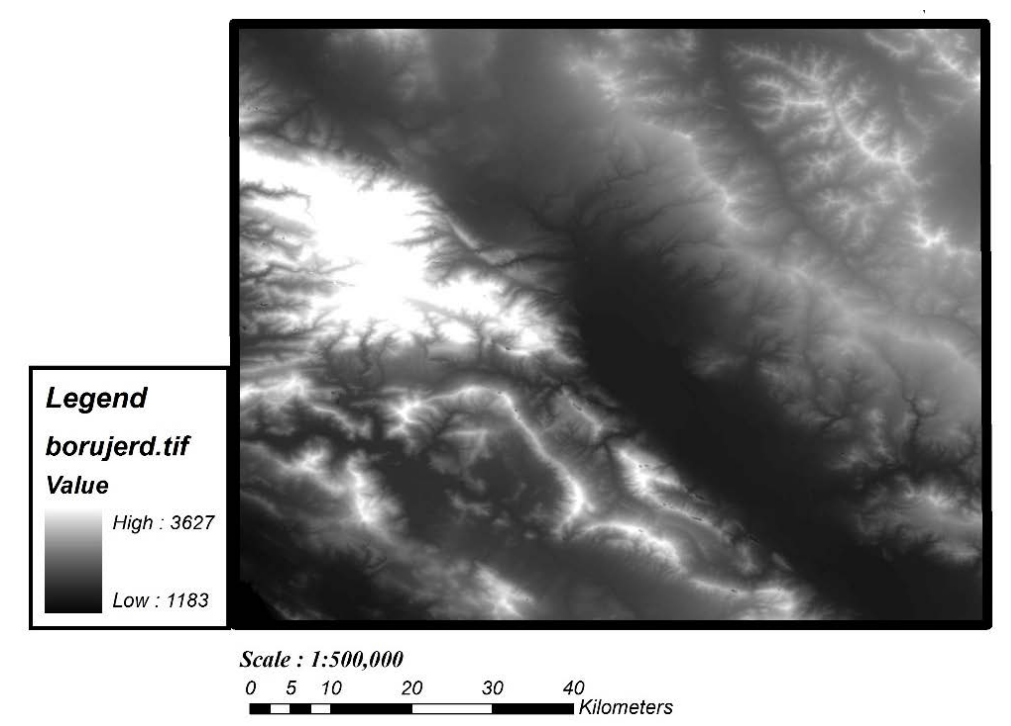

Figure 2. Digital elevation model of the Boroujerd area. 


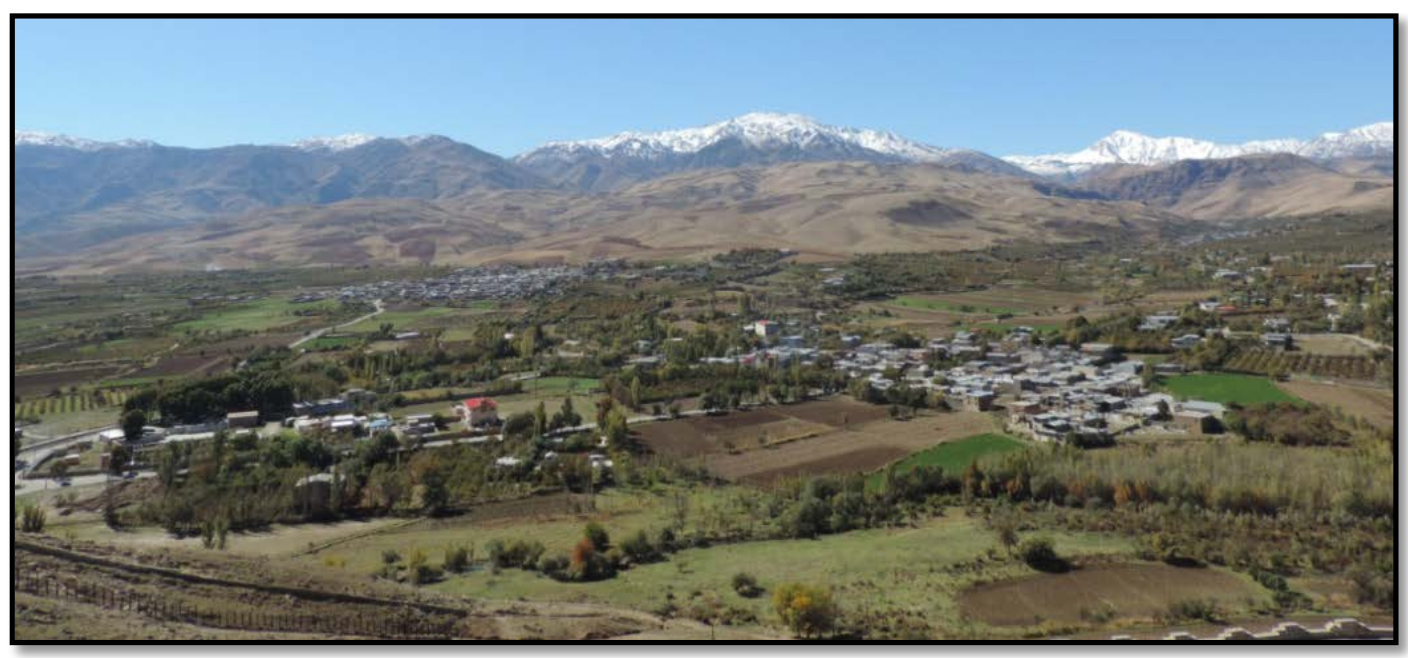

Figure 3. The Ghaleh Hatam fault (boundary of mountain and plain) in the north eastern part of Boroujerd city, view to the east.
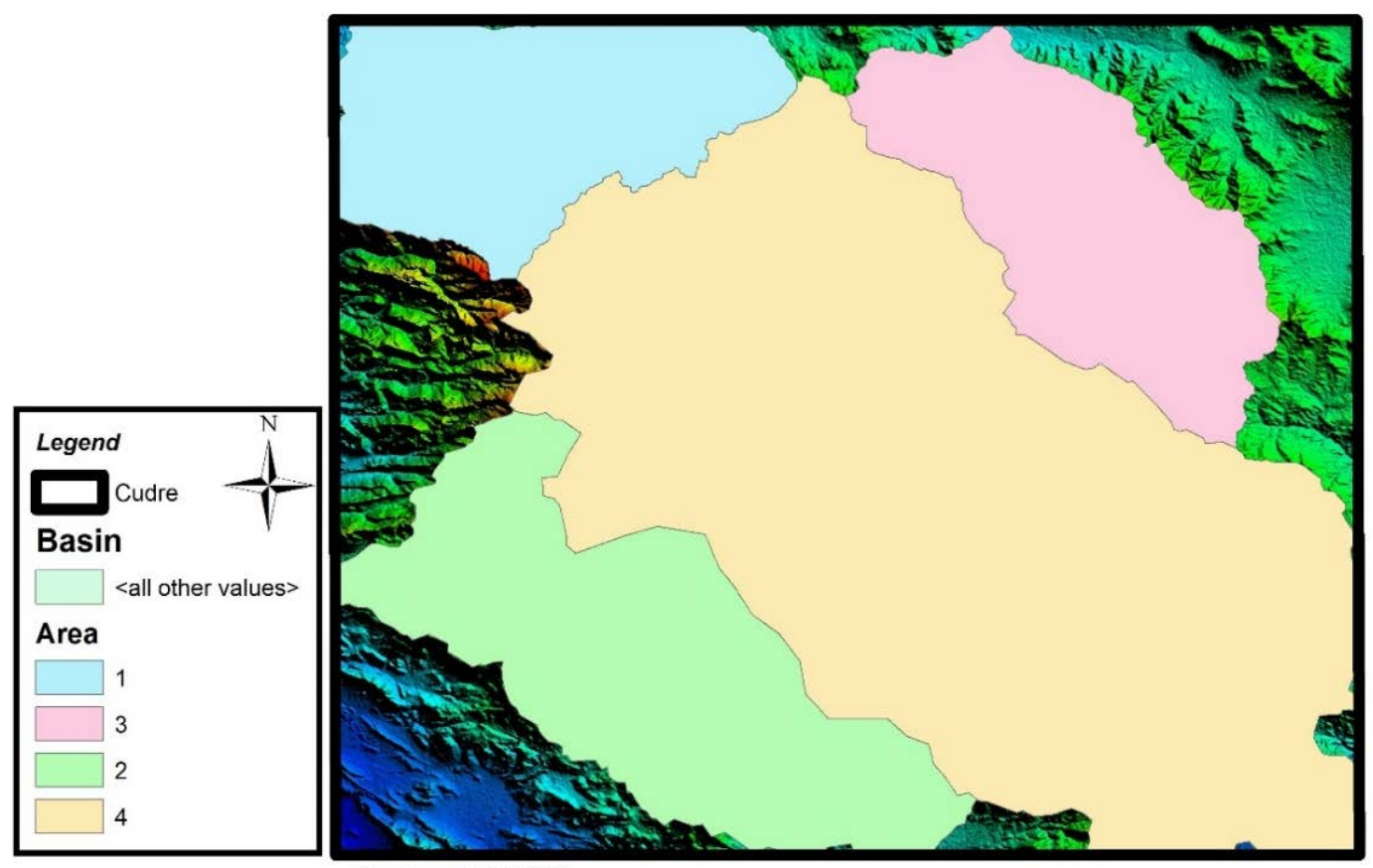

Scale : 1:500,000

$01020 \quad 40 \quad 60$

Kilometers

Figure 4. Determination of sub-basins in the Boroujerd area based on Digital Elevation model (DEM).

calculated along the four master rivers (Table 1) and then SL graphs have prepared for them (Figure 5). The SL index can be used to evaluate relative tectonic activity. An area on soft rocks with high $S L$ values can be indicated for active tectonics. Based on our results, there are in 2 and 3 classes.

\subsection{Valley Floor Width-Valley Height Ratio ( $V f$ )}

Another index sensitive to tectonic uplift is the valley floor width to valley height ratio $(V f)$. This index can separate v-shaped valleys with small amounts from u-shaped valleys with greater amounts. The calculation formula is in this manner: 

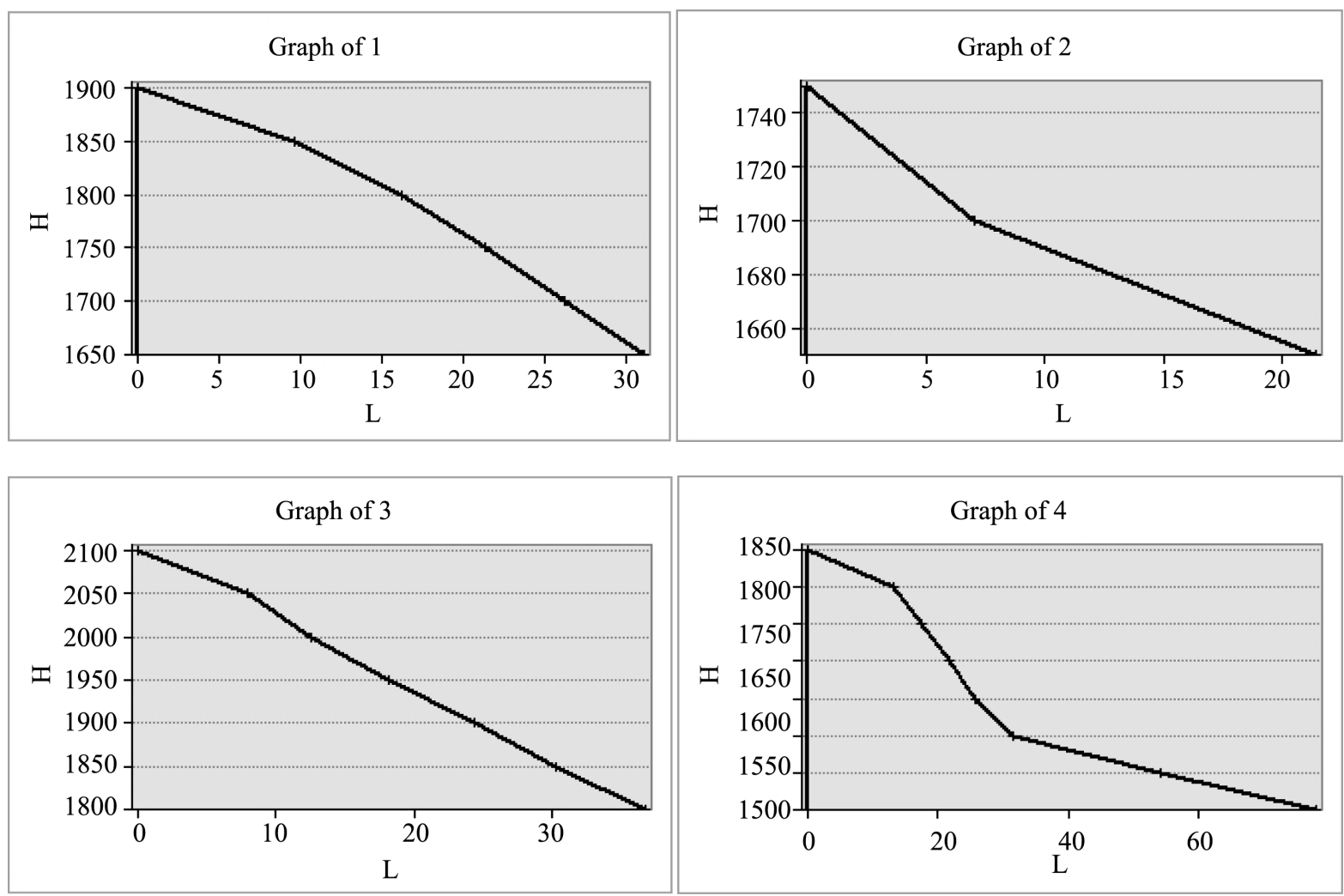

Figure 5. Graphs of stream length-gradient index for 4 rivers.

Table 1. Values of stream length-gradient index.

\begin{tabular}{|c|c|c|c|c|c|}
\hline SL(1) & $\mathbf{L}$ & $\Delta \mathbf{L}$ & $\Delta \mathbf{H} / \Delta \mathbf{h}$ & $\Delta \mathbf{h} \mathbf{2}$ & $\Delta \mathbf{H}$ \\
\hline 12.06 & 31.08 & 4.38 & 50 & 1650 & 1700 \\
\hline 8.56 & 26.21 & 5.36 & 50 & 1700 & 1750 \\
\hline 8.81 & 21.35 & 4.36 & 50 & 1750 & 1800 \\
\hline 4.99 & 16.17 & 6 & 50 & 1800 & 1850 \\
\hline 2.62 & 9.67 & 7 & 50 & 1850 & 1900 \\
\hline
\end{tabular}

Class 2

\begin{tabular}{ccccccc}
\hline SL(2) & $\mathbf{L}$ & $\Delta \mathbf{L}$ & $\Delta \mathbf{H} / \Delta \mathbf{h}$ & $\Delta \mathbf{h} \mathbf{2}$ & $\Delta \mathbf{H}$ \\
\hline $\mathbf{1 . 8 8}$ & 21.39 & 19.30 & 50 & 1650 & 1700 \\
$\mathbf{1 . 3 0}$ & 7.02 & 9.44 & 50 & 1700 & 1750
\end{tabular}

Class 3

\begin{tabular}{|c|c|c|c|c|c|}
\hline SL(3) & $\mathbf{L}$ & $\Delta \mathbf{L}$ & $\Delta \mathbf{H} / \Delta \mathbf{h}$ & $\Delta \mathrm{h} 2$ & $\Delta \mathbf{H}$ \\
\hline 8.92 & 36.78 & 7.63 & 50 & 1800 & 1850 \\
\hline 8.90 & 30.36 & 6.48 & 50 & 1850 & 1900 \\
\hline 8.48 & 24.32 & 5.59 & 50 & 1900 & 1950 \\
\hline 5.6 & 18.2 & 6.5 & 50 & 1950 & 2000 \\
\hline 5.47 & 12.6 & 4.72 & 50 & 2000 & 2050 \\
\hline 3.5 & 7.9 & 4.7 & 50 & 2050 & 2100 \\
\hline Class 3 & & & & & \\
\hline
\end{tabular}




\begin{tabular}{|c|c|c|c|c|c|}
\hline SL(4) & $\mathrm{L}$ & $\Delta \mathrm{L}$ & $\Delta \mathrm{H} / \Delta \mathrm{h}$ & $\Delta \mathrm{h} 2$ & $\Delta \mathrm{H}$ \\
\hline 13.82 & 78.12 & 8.76 & 50 & 1500 & 1550 \\
\hline 22.25 & 54.24 & 3.9 & 50 & 1550 & 1600 \\
\hline 7.94 & 31.47 & 6.54 & 50 & 1600 & 1650 \\
\hline 9.39 & 25.86 & 4.68 & 50 & 1650 & 1700 \\
\hline 9.79 & 21.26 & 3.80 & 50 & 1700 & 1750 \\
\hline 6.83 & 17.42 & 4.59 & 50 & 1750 & 1800 \\
\hline 1.7 & 13.1 & 14.06 & 50 & 1800 & 1850 \\
\hline Class 2 & & & & & \\
\hline
\end{tabular}

$$
V f=2 V f w /(E l d+E r d-2 E s c)
$$

where $V f w$ is the width of the valley floor, and Eld, Erd and Esc are the altitudes of the left and right divisions (looking downstream) and the stream channel, respectively [84]. [4] found significant differences in $V f$ between tectonically active and inactive mountain fronts. Also, they found significant differences in $V f$ between tectonically active and inactive mountain fronts, because a valley floor is narrowed due to rapid stream down cutting.

So, we have considered suitable valleys in the study area (Figure 6).

$V f w$ value is obtained by measuring the length of a line which cuts the river and limits to two sides of a contour through which the river crosses (Table 2). Based on [11], $V f$ values are divided into 3 classes: 1 ( Vf<0.3), $2(0.3<V f<1)$, and $3(V f>1)$. Therefore, all of the valleys are in 2 and 3 classes and show $U$ shape valleys.

\subsection{Mountain-Front Sinuosity Index (Smf)}

This index represents a balance between stream erosion processes tending to cut some parts of a mountain front and active vertical tectonics that tend to produce straight mountain fronts. Index of mountain front sinuosity [3] is defined by:

$$
S m f=L j / L s
$$

where $L j$ is the planimetric length of the mountain along the mountain-piedmont junction, and Ls is the straightline length of the front. The Mountain fronts of the study area have drawn in Figure 7 by and one of them in sub-basin No. 2 has shown in Figure 8. Smf is commonly less than 3, and approaches 1 where steep mountains rise rapidly along a fault or fold [84]. Therefore, this index can play an important role in tectonic activity. Considering that mountain fronts sites are independent from basins places, chances are some of them have various fronts (Table 3). Values of Smf are readily calculated from topographic maps for 4sub-basins.

Based on [11], Smf values are divided into 3 classes: $1(\operatorname{Smf}<1.1), 2(1.1<\operatorname{Smf}<1.5)$, and $3(\operatorname{Smf}>1.5)$ and in the study area most of the obtained values are between 1.1 to 1.5 (class 2).

\subsection{Asymmetry Factor (Af)}

This index is related to two tectonic and none tectonic factors. None tectonic factors may relate to lithology and rock fabrics. It is a way to evaluate the existence of tectonic tilting at the scale of a drainage basin. The index is defined as follows:

$$
\text { Af }=(\text { Ar/At }) 100
$$

where $A r$ is the right side area of the master stream basin (looking downstream) and At is the total area of the basin that can be measured by GIS software. To calculate this index in the area At and Ar are obtained using the sub-basins and the master river maps. Af is close to 50 if there is no or little tilting perpendicular to the direction of the master stream. Af is significantly greater or smaller than 50 under the effects of active tectonics or strong lithologic control. The values of this index are divided into three categories. 1: (Af<35 or Af $>63) 2:(57<A f$ $<65)$ or $(35<A f<43)$ and 3: $(43<A f<57)$, based on [11].

Among the obtained values (Table 4), the minimum value belongs to sub-basin No. 4 with 41.96 and the maximum value belongs to sub-basin No. 2 with 61.81 percents. Also, a map has prepared that it shows Asymmetry factor of study area (Figure 9). 
Table 2. Values of $V f$ index.

\begin{tabular}{|c|c|c|c|c|c|c|c|c|}
\hline Basin & Sub-Basin & $V_{f w}$ & $E_{l d}$ & $E_{s c}$ & $E_{r d}$ & $V_{f}$ & Average & Class \\
\hline \multirow{5}{*}{1} & $1 \mathrm{a}$ & 150 & 1930 & 1750 & 1930 & 0.83 & \multirow{5}{*}{8.08} & \multirow{5}{*}{3} \\
\hline & $1 \mathrm{~b}$ & 600 & 2020 & 1820 & 1940 & 3.75 & & \\
\hline & 1c & 200 & 1910 & 1760 & 1970 & 1.11 & & \\
\hline & $1 d$ & 800 & 1920 & 1810 & 1848 & 10.81 & & \\
\hline & $1 \mathrm{e}$ & 1910 & 1910 & 1880 & 2010 & 23.88 & & \\
\hline \multirow{12}{*}{2} & $2 a$ & 70 & 2100 & 1610 & 2000 & 0.16 & \multirow{12}{*}{1.64} & \multirow{12}{*}{3} \\
\hline & $2 \mathrm{~b}$ & 800 & 2000 & 1610 & 2050 & 1.93 & & \\
\hline & $2 c$ & 800 & 2600 & 1620 & 2400 & 0.91 & & \\
\hline & $2 \mathrm{~d}$ & 150 & 1810 & 1740 & 1970 & 1.00 & & \\
\hline & $2 e$ & 700 & 1930 & 1700 & 2400 & 1.51 & & \\
\hline & $2 f$ & 200 & 2050 & 1650 & 2300 & 0.38 & & \\
\hline & $2 \mathrm{~g}$ & 100 & 2000 & 1800 & 2080 & 0.42 & & \\
\hline & $2 \mathrm{~h}$ & 800 & 1980 & 1610 & 2080 & 1.90 & & \\
\hline & $2 \mathrm{i}$ & 400 & 1810 & 1680 & 2040 & 1.63 & & \\
\hline & $2 j$ & 800 & 1760 & 1660 & 1860 & 5.33 & & \\
\hline & $2 \mathrm{k}$ & 500 & 1850 & 1690 & 1940 & 2.44 & & \\
\hline & $2 \mathrm{l}$ & 500 & 1850 & 1680 & 1980 & 2.13 & & \\
\hline \multirow{6}{*}{3} & 3a & 2000 & 2100 & 1810 & 2040 & 7.69 & \multirow{6}{*}{2.35} & \multirow{6}{*}{3} \\
\hline & $3 b$ & 200 & 2160 & 2050 & 2390 & 0.89 & & \\
\hline & 3c & 1500 & 1980 & 1880 & 2350 & 5.26 & & \\
\hline & $3 d$ & 700 & 2280 & 2050 & 2440 & 2.26 & & \\
\hline & 3e & 200 & 2170 & 2010 & 2250 & 1.00 & & \\
\hline & $3 f$ & 200 & 2250 & 2000 & 2400 & 0.62 & & \\
\hline \multirow{10}{*}{4} & $4 a$ & 300 & 2700 & 2510 & 2900 & 1.03 & \multirow{10}{*}{0.80} & \multirow{10}{*}{2} \\
\hline & $4 \mathrm{~b}$ & 100 & 2100 & 1750 & 2000 & 0.33 & & \\
\hline & $4 c$ & 500 & 1790 & 1710 & 1800 & 5.88 & & \\
\hline & $4 d$ & 1000 & 2050 & 1650 & 1850 & 3.33 & & \\
\hline & $4 e$ & 200 & 1840 & 1710 & 2000 & 0.95 & & \\
\hline & $4 \mathrm{f}$ & 150 & 1930 & 1610 & 1880 & 0.51 & & \\
\hline & $4 \mathrm{~g}$ & 800 & 1690 & 1960 & 1900 & 4.85 & & \\
\hline & $4 \mathrm{~h}$ & 400 & 2690 & 1800 & 2700 & 0.45 & & \\
\hline & $4 \mathrm{i}$ & 150 & 2750 & 1700 & 2600 & 0.15 & & \\
\hline & $4 j$ & 100 & 2400 & 1720 & 2150 & 0.18 & & \\
\hline
\end{tabular}

Table 3. Values of Smf index.

\begin{tabular}{|c|c|c|c|c|}
\hline Sub-Basin & $L_{s}$ & $L_{m f}$ & $S_{m f}$ & Class \\
\hline 1 & 24 & 26 & 1.08 & 1 \\
\hline 2 & 23 & 26 & 1.13 & 2 \\
\hline 3 & 28 & 34 & 1.21 & 2 \\
\hline 4 & 21 & 30 & 1.42 & 2 \\
\hline
\end{tabular}


Table 4. Values of $A f$ index.

\begin{tabular}{cccccc}
\hline Sub-Basin & Ar & At & Af & Class \\
$\mathbf{1}$ & 233.7 & 538 & 43.44 & 2 \\
$\mathbf{2}$ & 501.9 & 812 & 51.81 & 50.8 \\
$\mathbf{3}$ & 297.2 & 585 & 41.96 & 2 \\
\hline
\end{tabular}

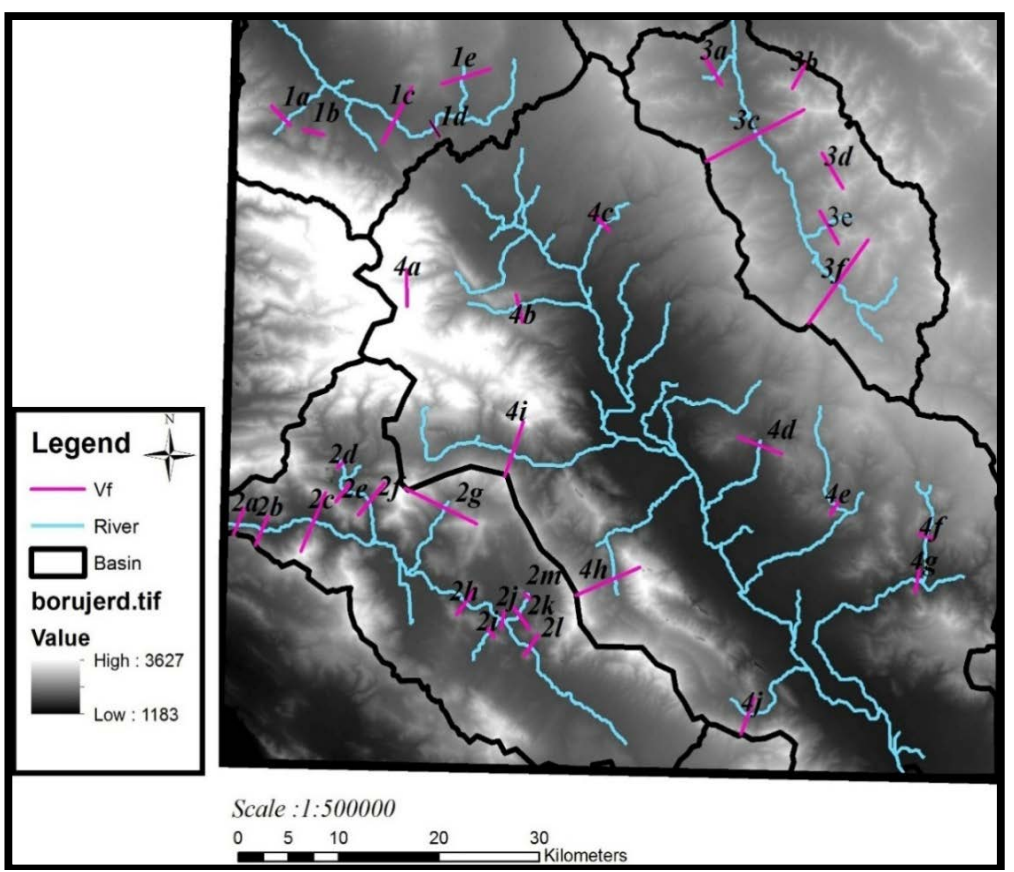

Figure 6. Position map for measurement of the valley floor width to valley height ratio.

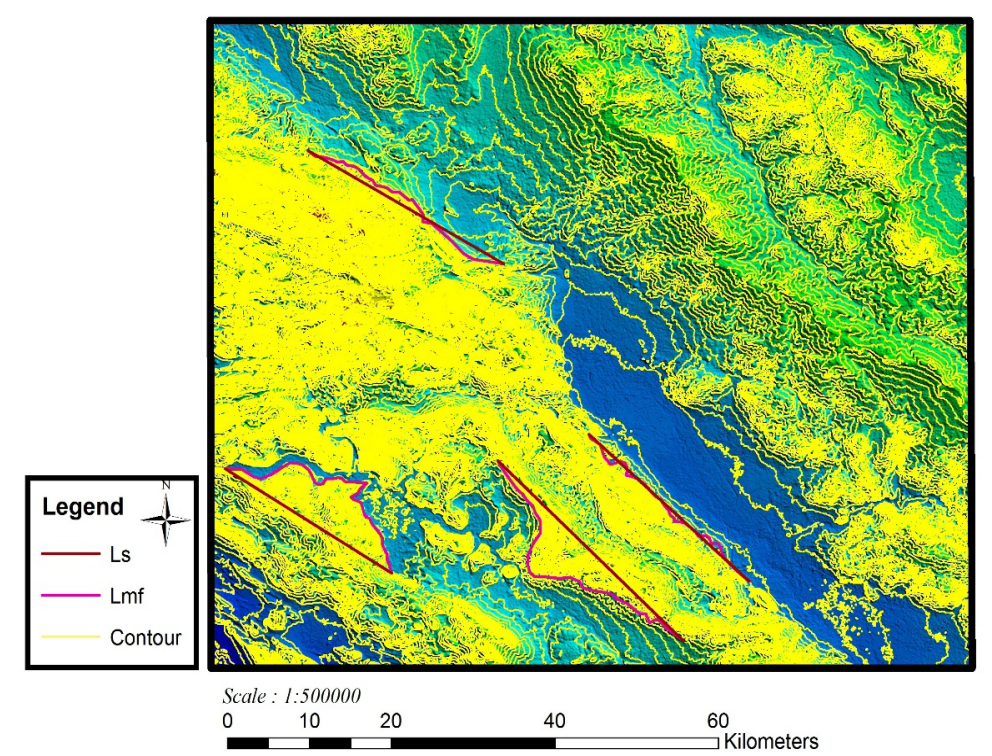

Figure 7. Position map for measurement of mountain-front sinuosity index. 


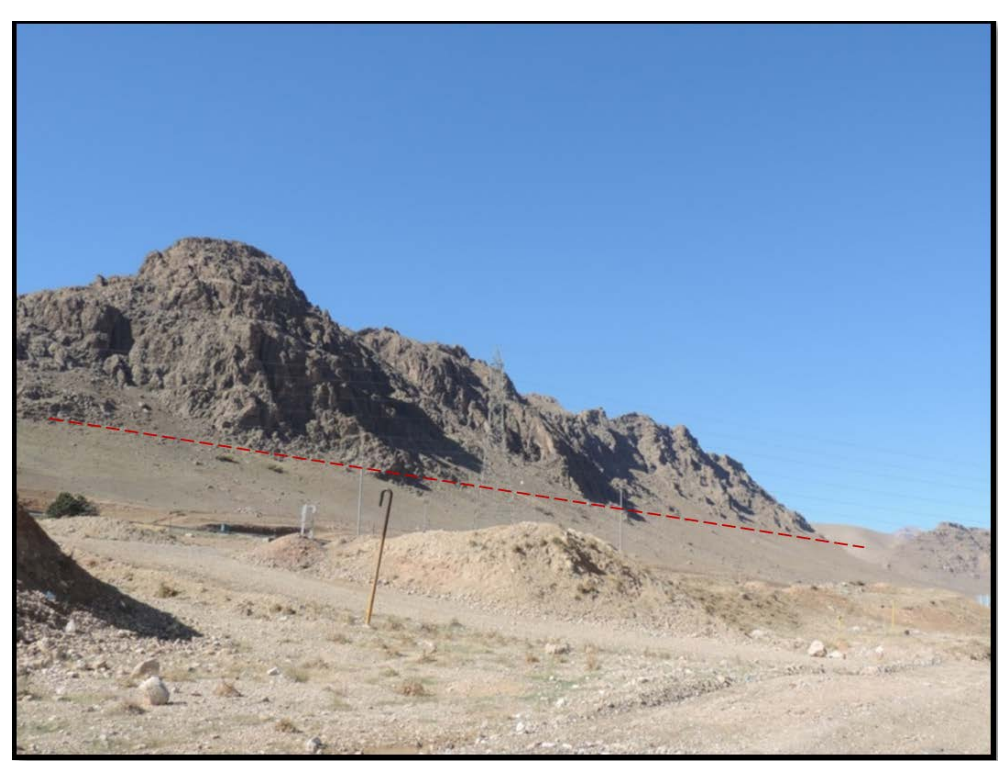

Figure 8. A Mountain-front in the south western part of Boroujerd city (subbasin No. 2), view to the SW.

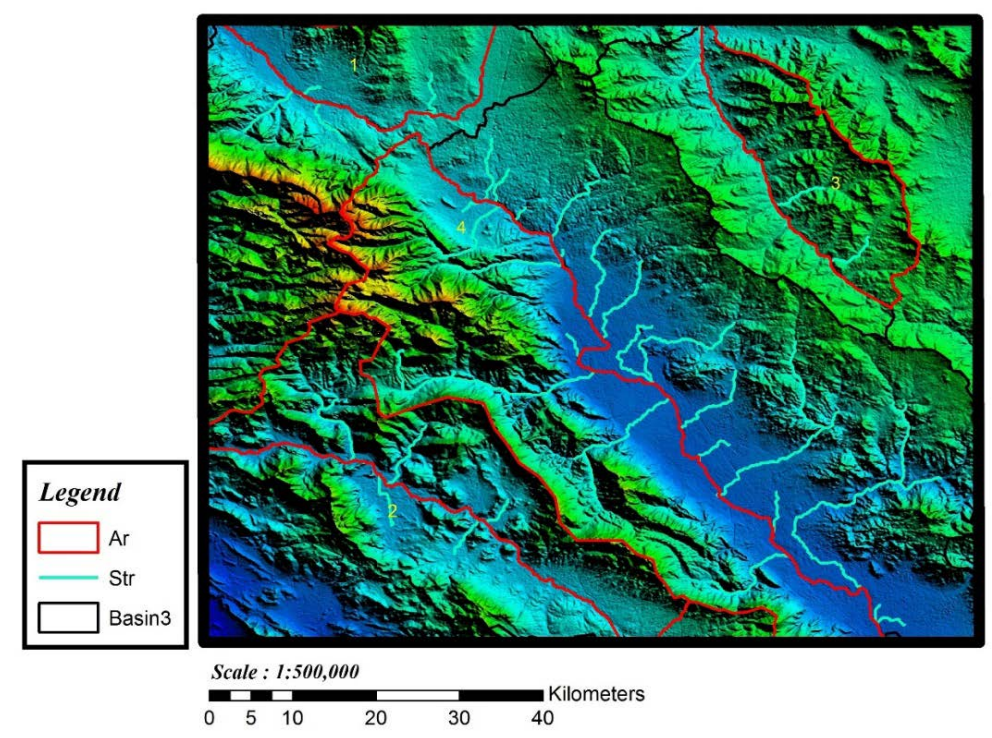

Figure 9. Asymmetry factor map of study areas.

\subsection{Basin Shape Index (BS)}

Relatively young drainage basins in active tectonic areas tend to be more elongated than their normal shape to the topographic slope of a mountain. The elongated shape tends to evolve into a more circular shape [4]. The horizontal projection of the basin shape may be described by the basin shape index or the elongation ratio, Bs [7]. The calculation formula is:

$$
B s=B l / B w
$$

where $B l$ is the length of the basin measured from the headwater to the mount, and $B w$ is basin width in the widest point of the basin $B l$.

To calculate this index in the area, $B l$ and $B w$ are obtained using the sub-basins and the master river maps then the values are divided into 3 classes: 1: $(B s>4)$ 2: $(3<B s<4)$ 3: (Bs $<3)$, based on [11]. According to Figure 10 
and Table 5). The minimum value belongs to sub-basin No. 1 with 1 and the maximum value belongs to subbasin No. 2 with 2.4 (Class 3).

\subsection{Hypsometric Integral Index ( $\mathrm{Hi})$}

The hypsometric integral $\mathrm{Hi}$ ) describes the relative distribution of elevation in a given area of a landscape particularly a drainage basin. The index is defined as the relative area below the hypsometric curve and it is an important indicator for topographic maturity. $H_{\max }, H_{\min }$ and $H_{\text {ave }}$ are calculated on DEM. This index is calculated to all sub-basins in the area and the minimum value is 0.19 for sub-basin No. 2 and maximum value is 0.50 for sub-basin No. 3 (Table 6). The hypsometric integral reveals the maturity stages of topography that can, indirectly, be an indicator of active tectonics. In general, high values of the hypsometric integral are convex, and these values are generally $>0.5$. Intermediate values tend to be more concave-convex or straight, and generally have values between 0.4 and 0.5 . Finally, lower values $(<0.4)$ tend to have concave shapes [11]. We can consider class 1 for $\mathrm{Hi}>0.5$, class 2 for Hi between 0.4 and 0.5 and class 3 for $\mathrm{Hi}<0.4$ and so, sub-basin No. 3 shows younger topography.

\section{Results and Discussion}

The average of the six measured geomorphic indices ( $V f$, Smf, SL, Af, Bs and $H i$ ) was used to evaluate the distribution of relative tectonic activity. Through averaging these six indices (Table 7). we obtain one index that is known index of active tectonics (Iat). The values of the index were divided into four classes to define the degree of active tectonics: 1 -very high $(1<$ Iat $<1.5)$, 2-high $(1.5<$ Iat $<2)$, 3-moderate $(2<$ Iat $<2.5)$, 4-low $(2.5<$ Iat $)$ [11].

Thus, there are low relative tectonic activities in sub-basin No. 1, 2 and 3 and moderate relative tectonic activities in sub-basin No. 4 (Figure 11). The sub-basin No. 4 has situated in the middle part of study area and it has got several faults that shown in Figure 12.

Also, based on [23], this area is a high seismic risk zone with following seismicity parameter: $b=1.06, \mathrm{M}$ $\max =7.2$. Focal mechanisms of several earthquakes are dextral strike slip in relation to main recent faults of Zagros such as Doroud (Ms $=6.1,2006)$.

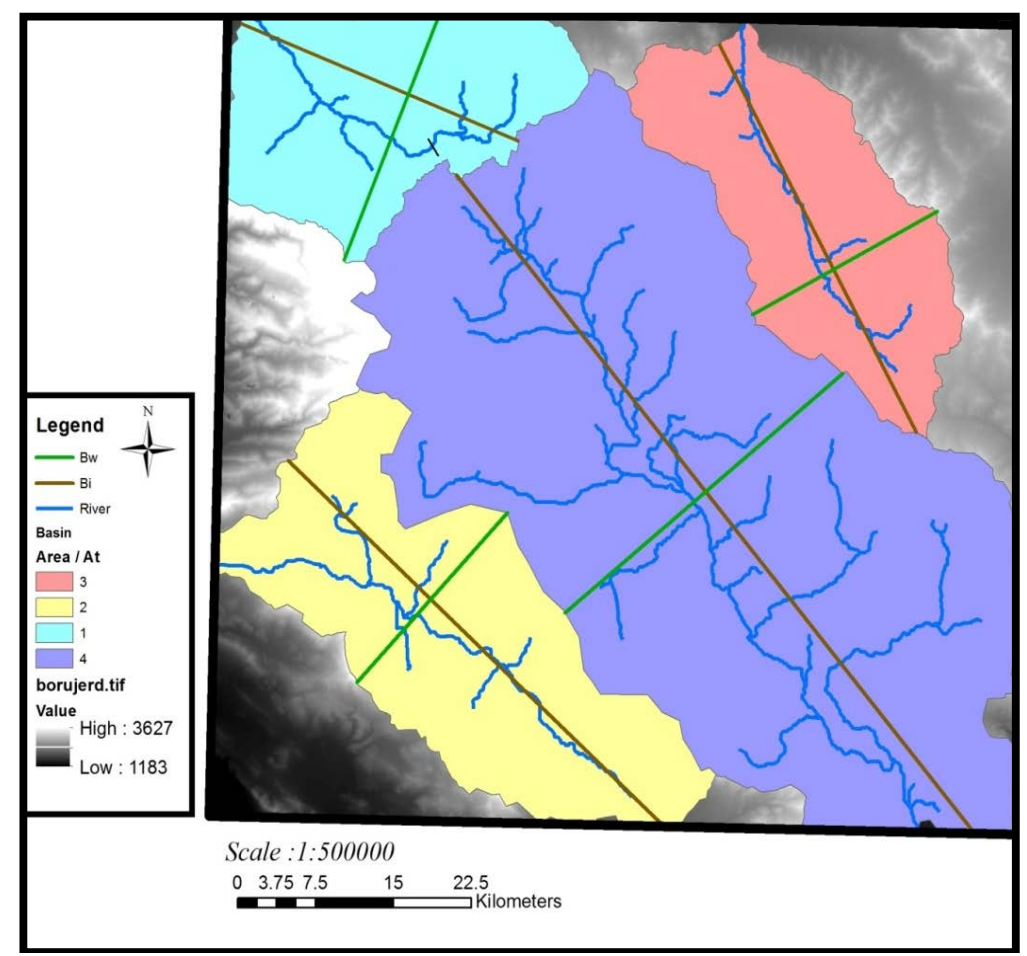

Figure 10. Basin shape map of study area. 
Table 5. Values of Bs index.

\begin{tabular}{ccccc}
\hline Sub-Basin & $\boldsymbol{B}_{\boldsymbol{i}}$ & $\boldsymbol{B}_{\boldsymbol{w}}$ & $\boldsymbol{B}_{\mathbf{s}}$ & Class \\
\hline $\mathbf{1}$ & 30.71 & 30.68 & 1 & 3 \\
$\mathbf{2}$ & 51.86 & 21.05 & 2.4 & 3 \\
$\mathbf{3}$ & 41.25 & 19.56 & 2.1 & 3 \\
$\mathbf{4}$ & 74.09 & 36.24 & 2.04 & 3 \\
\hline
\end{tabular}

Table 6. The hypsometric integral (Hi).

\begin{tabular}{cccccc}
\hline Sub-Basin & $\boldsymbol{H}_{\text {ave }}$ & $\boldsymbol{H}_{\max }$ & $\boldsymbol{H}_{\min }$ & $\boldsymbol{H}_{\boldsymbol{i}}$ & Class \\
\hline $\mathbf{1}$ & 2044.54 & 3036 & 1609 & 0.30 & 3 \\
$\mathbf{2}$ & 1884.70 & 2932 & 1631 & 0.19 & 3 \\
$\mathbf{3}$ & 2131.58 & 2425 & 1838 & 0.50 & 2 \\
$\mathbf{4}$ & 1868.98 & 3250 & 1440 & 0.23 & 3 \\
\hline
\end{tabular}

Table 7. Relative Tectonic activity classification.

\begin{tabular}{|c|c|c|c|c|c|c|c|c|}
\hline Sub-Basin & $S_{m f}$ & $V_{f}$ & $S_{l}$ & $A_{f}$ & $\boldsymbol{B}_{s}$ & $\boldsymbol{H}_{\boldsymbol{i}}$ & $\mathbf{s} / \mathbf{n}$ & IAT \\
\hline 1 & 1 & 3 & 2 & 3 & 3 & 3 & 2.5 & 4 \\
\hline 2 & 2 & 3 & 3 & 2 & 3 & 3 & 2.6 & 4 \\
\hline 3 & 2 & 3 & 3 & 3 & 3 & 2 & 2.6 & 4 \\
\hline 4 & 2 & 2 & 2 & 2 & 3 & 3 & 2.3 & 3 \\
\hline
\end{tabular}

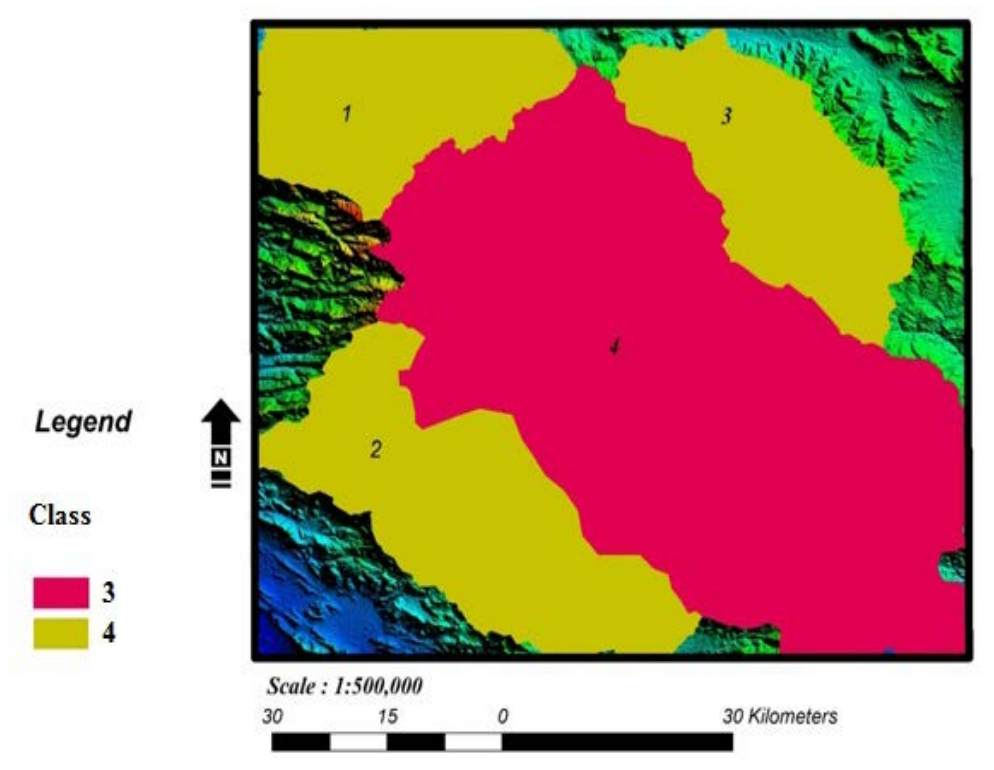

Figure 11. Relative Tectonic activity classification map of study area.

This area is struck by moderate to high earthquakes with low frequency, long repeat time and 10 - 15 Km focal depth. Intensity of earthquakes is in high levels. Sometimes, focal depths exceed to $70 \mathrm{Km}$ which is an indication of initial stages of thick-skinned tectonics. The most serious seismic hazards in the study area are landslide in high regions, settlement in plain, surface faulting (Figure 13). 


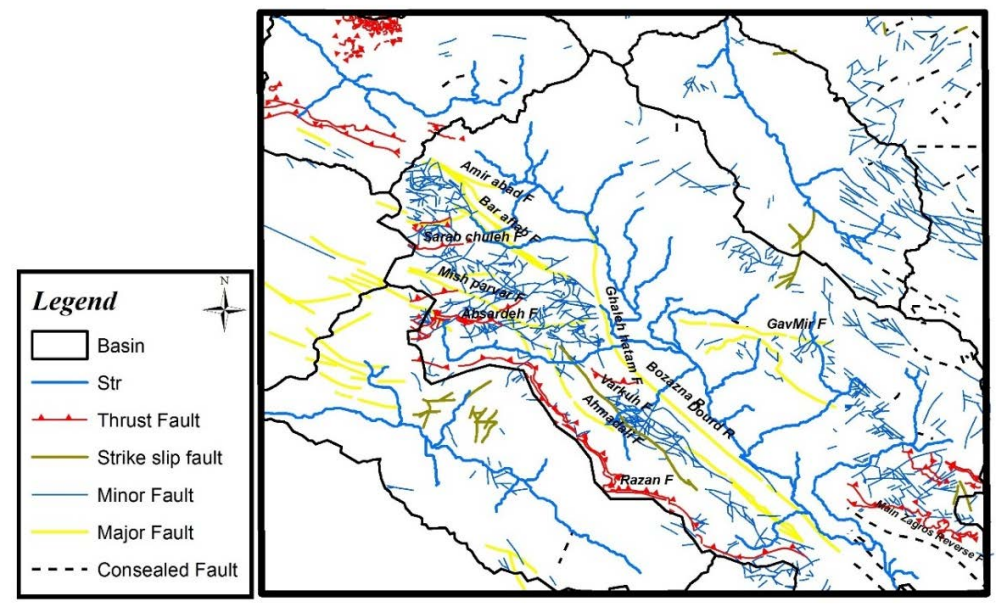

Figure 12. Fault map of study area.

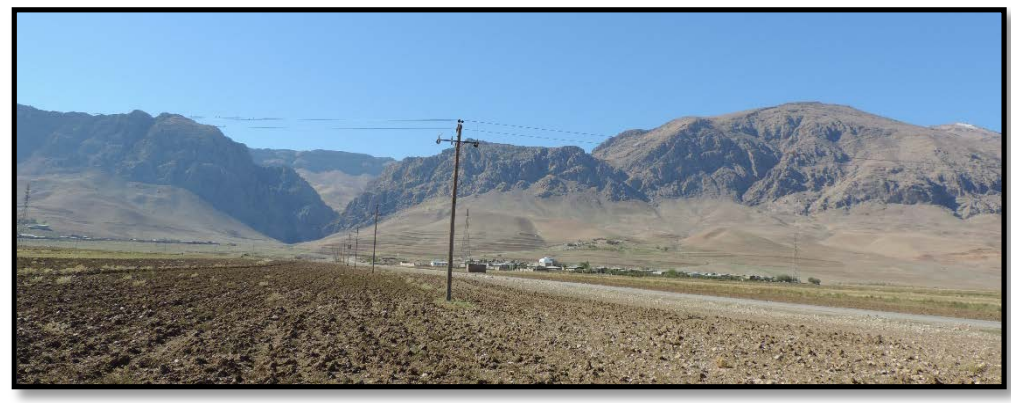

Figure 13. The Doroud fault, view to the south.

\section{Conclusions}

The calculated geomorphic indices are suitable for assessment of tectonic activity of the study area. The six geomorphic indices; stream-gradient index $(S l)$, valley floor width-valley height ratio $(V f)$ and mountain-front sinuosity $(\mathrm{Sm} f)$, drainage basin asymmetry (Af), hypsometric integral $(\mathrm{Hi})$ and drainage basin shape (Bs) have been calculated in Boroujerd area.

Therefore, firstly the area was divided to sub-basins and for each one, indices were calculated, then all of the indices were divided into relative tectonic activity classes. Afterwards, the six measured indices for each subbasin were compounded and a unit index obtained as index of active tectonics (Iat). According to this index, there are both low and moderate relative tectonic activities levels.

Low relative tectonic activities level has been found in sub-basin No. 1, 2 and 3 and moderate relative tectonic activities level, has been found in sub-basin No. 4. It means that sub-basin No. 4 has got the more active uplifting by movements of several faults such as Doroud fault.

\section{Acknowledgements}

This work has funded by the Department of geology, Islamic Azad University, Science and Research branch, Tehran, Iran. Also, Special thanks to vice-president for research in Science and Research branch, Tehran.

\section{References}

[1] Arian, M. (2013) Physiographic-Tectonic Zoning of Iran’s Sedimentary Basins. Open Journal of Geology, 3, $169-177$. http://dx.doi.org/10.4236/ojg.2013.33020

[2] Qorashi, M. and Arian, M. (2011) Tectonics of Iran. Geologic Survey of Iran, Tehran, 336 p.

[3] Arian, M. (2011) Basement Tectonics and Geology of Iran. AsarNafis Press, Qum, 300 p. 
[4] Bull, W.B. and McFadden, L.D. (1977) Tectonic Geomorphology North and South of the Garlock Fault, California. In: Doehring, D.O., Ed., Geomorphology in Arid Regions, Proceedings of the Eighth Annual Geomorphology Symposium, State University of New York, Binghamton, 115-138.

[5] Molin, P., Pazzaglia, F.J. and Dramis, F. (2004) Geomorphic Expression of Active Tectonics in a Rapidly-Deforming forearc, sila massif. Calabria, Southern Italy. American Journal of Science, 304, 559-589. http://dx.doi.org/10.2475/ajs.304.7.559

[6] Silva, P.G., Goy, J.L., Zazo, C. and Bardajm, T. (2003) Fault Generated Mountain Fronts in Southeast Spain: Geomorphologic Assessment of Tectonic and Earthquake Activity. Geomorphology, 250, 203-226.

[7] Keller, EA. and Pinter, N., (2002) Active Tectonics: Earthquakes, Uplift, and Landscape. Prentice Hall, New Jersey, 432.

[8] Rockwell, T.K., Keller, E.A. and Jonson, D.L. (1985) Tectonic Geomorphology of Alluvial Fans and Mountain Fronts near Ventura, California. In: Morisawa, M., Ed., Tectonic Geomorphology, Proceedings of the 15th Annual Geomorphology Symposium, Allen and Unwin Publishers, Boston, 183-207.

[9] Wells, S.G., Bullard, T.F., Menges, T.M., Drake, P.G., Karas, P.A., Kelson, K.I., Ritter, J.B. and Wesling, J.R. (1988) Regional Variations in Tectonic Geomorphology along Segmented Convergent Plate Boundary. Geomorphology, 1, 239-265.

[10] Dehbozorgi, M., Pourkermani, M., Arian, M., Matkan, A.A., Motamedi, H. and Hosseiniasl, A. (2010) Quantitative Analysis of Relative Tectonic Activity in the Sarvestan Area, Central Zagros, Iran. Geomorphology, 121, 329-341.

[11] El Hamdouni, R., Irigaray, C., Fernández, T., Chacón, J. and Keller, E.A. (2008) Assessment of Relative Active Tectonics, Southwest Border of Sierra Nevada (Southern Spain). Geomorphology, 96, 150-173. http://dx.doi.org/10.1016/j.geomorph.2007.08.004

[12] Arian, M. (2011) A Preface on Salt Diapirism of Iran. AsarNafis Press, Qum, 309 p.

[13] Arian, M. and Noroozpour, H. (2015) The Biggest Salt-Tongue Canopy of Central Iran. Open Journal of Geology, 5, 55-60. http://dx.doi.org/10.4236/ojg.2015.52005

[14] Asadian, F., Pourkermani, M. and Arian, M. (2007) Tectonic Geomorphology of Salt Structures in the GarmsarLasjerd Area. Geographical Research, 39, 75-84.

[15] Pourkermani, M. and Arian, M. (1997). Salt Domes of Central Iran. Journal of Humanities, 3, 29-41.

[16] Arian, M. (2012) Salt Diapirism and Tectonics. 2nd Edition, AsarNafis Press, Qum, 319 p.

[17] Arian, M. and Noroozpour, H. (2015) Tectonic Geomorphology of Iran’s Salt Structures. Open Journal of Geology, 5, 61-72. http://dx.doi.org/10.4236/ojg.2015.52006

[18] Asadian, F. and Arian, M. (2009) Identification of Diapiric Provinces of Central Iran through Geological and Geographical Analysis. International Journal of Agriculture Environment \& Biotechnology, 2, 3443-3451.

[19] Arian, M. (2012) Clustering of Diapiric Provinces in the Central Iran Basin. Carbonates and Evaporites, 27, 9-18. http://dx.doi.org/10.1007/s13146-011-0079-9

[20] Pourkermani, M. and Arian, M. (1998) Tectonic Geomorphology of Salt Domes in West of Zanjan Province, Iran. Geographical Research, 47, 44-53.

[21] Arian, M. and Feizi, F. (2010) The Significance of Faulting on the Surficial Spreading of Evaporitic Deposits in the Varamin-Semnan Area. Journal of Earth and Resources, 3, 1-20.

[22] Arian, M. (2011) Middle East Tectonics. AsarNafis Press, Qum, 236 p.

[23] Arian, M. (2010) Applied Seismotectonics. Farazamin Press, Tehran, 304 p.

[24] Arian, M. and Maleki, R. (2008) Neotectonics. Farazamin Research Center, Tehran, 150.

[25] Pourkermani, M. and Arian, M. (1998) Seismicity of Iran. Shahid Beheshti University Press, Tehran, 212.

[26] Pourkermani, M. and Arian, M. (1997) Seismotectonics. Dez Ab Consulting Engineers Company Press, Tehran, 270.

[27] Arian, M. and Aram, Z. (2014) Relative Tectonic Activity Classification in the Kermanshah Area, Western Iran. Solid Earth, 5, 1277-1291. http://dx.doi.org/10.5194/se-5-1277-2014

[28] Mashal, M., Kermani, M.P., Charchi, A., Almasian, M. and Arian, M. (2013) Pattern of Structural Geology Underground in Eastern of North DEZFOL Embayment. Advances in Environmental Biology, 7, 260-268.

[29] Pazhoohan, M., Arian, M., Ghorashi, M. and Khosrotehrani, K. (2014) A Study of Drainage Pattern Responses to Active Tectonics in Tadvan Region, SW Iran. Geodynamics, 1, 36-41.

[30] Rahimi, N. and Arian, M. (2014) Tectonic Geomorphplogy of Hamedan-Sosangerd Region, West Iran. Advances in Environmental Biology, 8, 119-124.

[31] Arian, M. and Hashemi, A. (2008) Seismotectonic Zoning in the Zagros. Journal of Sciences, 18, 63-76. 
[32] Arian, M., Ahmadnia, A., Qorashi, M. and Pourkermani, M. (2002) Structural Analysis of Mengharak Transcurrent Fault System in Zagros, Iran. Special Geo 2002 Conference Issue Geoarabia, 7, 209-210.

[33] Arian, M., Qorashi, M., Pourkermani, M. and Ahmadnia, A. (2003) Fractal Analysis of Mengharak Transcurrent Fault System in Zagros, Iran. Abstracts of 4th International Conference on Seismology and Earthquake Engineering, Tehran, 12-14 May 2003, 23.

[34] Baharvand, S., Pourkermani, M., Ajalloian, R., Arian, M. and Nouryazdan, A.R. (2010) Seymareh Landslide and Its Role in Environmental and Geomorphologic Changes of the Pole-Dokhtar Area. Journal of the Earth, 4, 13-24.

[35] Abdideh, M., Qorashi, M., Rangzan, K. and Arian, M. (2011) Assessment of Relative Active Tectonics Using Morphometric Analysis, Case Study of Dez River (Southwestern, Iran). Geosciences, 20, 33-46.

[36] Arian, M., Qorashi, M., Pourkermani, M. and Ahmadnia, A. (2006) The Structural Significance Kareh Bas Transcurrent Fault System in the Zagros Fold and Thrust Belt. Journal of Geosciences, 15, 126-133.

[37] Arian, M., Maleki, Z. and Noroozpour, H. (2011) Cenozoic Diastrophism and Deformational Events in the East Central Alborz. Journal of Basic and Applied Scientific Research, 1, 2394-2400.

[38] Feizi, F., Arian, A. and Rahmani, R. (2007) Seismotectonic Zoning in the Eastern Part of the Central Alborz. Journal of Sciences, 17, 151-164.

[39] Khavari, R., Arian, M. and Ghorashi, M. (2009) Neotectonics of the South Central Alborz Drainage Basin, in NW Tehran, N Iran. Journal of Applied Sciences, 9, 4115-4126. http://dx.doi.org/10.3923/jas.2009.4115.4126

[40] Arian, M. and Bagha, N. (2012) Active Tectonics of Tehran Area, Iran. Journal of Basic and Applied Scientific Research, 2, 3805-3819.

[41] Bagha, N., Arian, M., Ghorashi, M., Pourkermani, M., El Hamdouni, R. and Solgi, A. (2014) Evaluation of Relative Tectonic Activity in the Tehran Basin, Central Alborz, Northern Iran. Geomorphology, 213, 66-87. http://dx.doi.org/10.1016/j.geomorph.2013.12.041

[42] Arian, M. and Feizi, F. (2005) Application of Geomorphic Indices to the Assessment of Relative Tectonic Activity Levels in the Alborz-Central Iran Border Zone. Journal of Sciences, 15, 378-403.

[43] Arian, M., Bagha, N., Khavari, R. and Noroozpour, H. (2012) Seismic Sources and Neo-Tectonics of Tehran Area (North Iran). Indian Journal of Science and Technology, 5, 2379-2383.

[44] Moghimi, H., Arian, M. and Sorbi, A. (2015) Fault Movement Potential of Marzanabad Area, North Alborz, Iran. Open Journal of Geology, 5, 126-135. http://dx.doi.org/10.4236/ojg.2015.53012

[45] Arian, M. and Pourkermani, M. (2004) Tectonic Elements of South Flank in the East-Central Alborz Mountain. Journal of Sciences, Teacher Training University, 4, 359-368.

[46] Arian, M. and Qorashi, M. (2006) The Movement Potential Evaluation of the Major Quaternary Faults in Alborz-Central Iran Border Zone, from the East of Tehran to the East of Semnan. Journal of Geosciences, Geological Survey of Iran, 15, 184-188.

[47] Poroohan, N., Pourkermani, M. and Arian, M. (2013) An Assessment of Relationship in F-Parameter and Paleostress Fields in Heterogeneous Lithologies: Roudbar Area (Northwest of Iran). Australian Journal of Basic \& Applied Sciences, 7, 933-942.

[48] Poroohan, N., Poukermani, M. and Arian, M. (2009) An Assessment on Correlations of Seismotectonic Parameters Preceding and Following Roudbar-Manjil Earthquake (Gilan, North of Iran). Australian Journal of Basic \& Applied Sciences, 3, 2643-2652.

[49] Farrokhnia, A.R., Pirasteh, S., Pourkermani, M. and Arian, M. (2011) Geo-Information Technology for Mass Wasting Hazard Zonation: Central-West Alborz-Iran. Disaster Advances, 4, 24-33.

[50] Khavari, R., Ghorashi, M. and Arian, M. (2009) Assessment of Relative Active Tectonics, South Central Alborz (North Iran). EGU General Assembly Conference Abstracts, 11, 1137.

[51] Sorbi, A., Arian, M. and Pourkermani, M. (2009) The Movement Potential Evaluation of the Major Quaternary Faults in Tehran Quadrangle. Journal of the Earth, 19, 176-182.

[52] Feizi, F. and Arian, M. (2006) The Classification of Thrust Fronts in the Alborz-Central Iran Border Zone from the East of Varamin to the East of Semnan. Journal of Sciences, 16, 75-87.

[53] Feizi, F. and Arian, M. (2005) Application of Geomorphic Indices to the Assessment of Relative Tectonic Activity Levels in the Alborz-Central Iran Border Zone. Journal of Science, 15,378-403.

[54] Arian, M. and Pourkermani, M. (2004) Structural Significance of North Semnan and Attary Faults in Alborz-Central Iran Border Zone. Journal of Science, 14, 4551-4569.

[55] Arian, M. and Pourkermani, M. (2005) Cenozoic Diastrophism and Deformational Events in the Southern Flank of Central-East Alborz. Journal of Faculty Earth Sciences, 10, 43-51. 
[56] Arian, M., Pourkermani, M., Qorashi, M. and Ghasemi, M.R. (2003) North Semnan Fault System and Its Role on Basin Division. 8th Symposium of Geological Society of Iran, Shahrood, September 2004, 11-17.

[57] Pourkermani, M. and Arian, M. (2001) Structural Geomorphology of Northeastern Kurdistan. Journal of Humanities, 7, 37-48.

[58] Mardani, Z., Ghorashi, M. and Arian, M. (2011) Geomorphic Signatures of Active Tectonics in the Talaghan Rud, Shah Rud and Sefidrud Drainage Basins in Central Alborz, N Iran. Geosciences, 20, 159-166.

[59] Sorbi, A., Arian, M. and Pourkermani, M. (2011) The Application of Geomorphic Indices to the Assessment of Relative Tectonic Activity Levels in Tehran Quadrangle. Journal of the Earth, 6, 1-9.

[60] Khavari, R., Ghorashi, M., Arian, M. and Khosrotehrani, K. (2010) Geomorphic Signatures of Active Tectonics in the Karaj Drainage Basin in South Central Alborz, N Iran. Geosciences, 19, 67-74.

[61] Mousavi, E.J. and Mehran, A. (2015) Tectonic Geomorphology of Atrak River, NE Iran. Open Journal of Geology, 5, 106-114. http://dx.doi.org/10.4236/ojg.2015.53010

[62] Nouri, R., Jafari, M.R., Arian, M., Feizi, F. and Afzal, P. (2013) Correlation between Cu Mineralization and Major Faults Using Multifractal Modelling in the Tarom Area (NW Iran). Geologica Carpathica, 64, 409-416. http://dx.doi.org/10.2478/geoca-2013-0028

[63] Nouri, R., Jafari, M.R., Arian, M., Feizi, F. and Afzal, P. (2013) Prospection for Copper Mineralization with Contribution of Remote Sensing, Geochemical and Mineralographical Data in Abhar 1:100,000 Sheet, NW Iran. Archives of Mining Sciences, 58, 1071-1084. http://dx.doi.org/10.2478/amsc-2013-0074

[64] Nouri, R., Afzal, P., Arian, M., Jafari, M. and Feizi, F. (2013) Reconnaissance of Copper and Gold Mineralization Using Analytical Hierarchy Process in the Rudbar 1:100,000 Map Sheet, Northwest Iran. Journal of Mining and Metallurgy, 49, 9-19.

[65] Arian, M. and Nouri, R. (2015) Lineament Tectonics and Mineralization in Tarom Area, North Iran. Open Journal of Geology, 5, 115-124. http://dx.doi.org/10.4236/ojg.2015.53011

[66] Feizi, F. and Arian, M. (2011) The Role of Structural Controllers in Geneses of Copper Deposits in 1:50000 Map of Saiin Qaleh. Journal of Sciences, 21, 1-10.

[67] Ehsani, J. and Arian, M. (2015) Quantitative Analysis of Relative Tectonic Activity in the Jarahi-Hendijan Basin Area, Zagros Iran. Geosciences Journal, 19, 1-15. http://dx.doi.org/10.1007/s12303-015-0016-3

[68] Bahiraee, S., Arian, M., Qorashi, M. and Solgi, M. (2015) The Movement Potential Evaluation of the Mosha Fault (the West of Firoozkuh to the Shahrestanak). Geosciences, 24, 123-126.

[69] Bagha, N., Ghorashi, M., Arian, M., Pourkermani, M. and Solgi, A. (2015) Neotectonic Analysis of Mosha-North Tehran Fault Zone, Based on Morphotectonic Features, Central Alborz, Northern Iran. Geosciences, 24, 41-52.

[70] Mosavi, J.E. and Arian, M. (2015) Neotectonics of Tabas Area, Central Iran by Index of Active Tectonics (IAT). Open Journal of Geology, 5, 209-223. http://dx.doi.org/10.4236/ojg.2015.54019

[71] Daryani, N.J., Arian, M. and Omran, N.R. (2015) Tectonics and Mineralization of Copper in the Ardestan-Kahang Area, Central Iran by Remote Sensing. Open Journal of Geology, 5, 188-196. http://dx.doi.org/10.4236/ojg.2015.54017

[72] Arian, M. and Pourkermani, M. (2001) Rivers Morphology and Active Tectonic (Reviewing the Current Status of Ghezel Ozon River in the Province of Zanjan). 5th Conference of Geological Society of Iran, Tehran, 28-30 August 2001, 556.

[73] Eshghi, Z., Arian, M. and Pourkermani, M. (2012) Structural Investigation on the Lak Mining Area (Bueen Zahra) Based on Remote Sensing, Used for Its Mineralization. Journal of the Earth, 6, 145-155.

[74] Arian, M., Toudeshki, V.H. and Noroozpour, H. (2011) Active Tectonics of Qezel Ozan River Basin, NW Iran. Journal of Applied Environmental and Biological Sciences, 1, 291-295.

[75] Alizadeh, H., Arian, M., Lotfi, M., Ghorashi, M. and Ghorbani, M. (2015) Determination of Porphyry Copper Deposit Locations Using Photo Lineament Factor in Northern Parts of the Dehaj-Sardoiyeh Belt. Geosciences, 24, $247-252$.

[76] Toudeshki, V.H., Pourkermani, M., Arian, M. and Khosrotehrani, K.H. (2011) Influence of Structures on the Ghezel Ozan River. Geosciences, 21, 55-60.

[77] Toudeshki, V.T. and Arian, M. (2011) Morphotectonic Analysis in the Ghezel Ozan River Basin, NW Iran. Journal of Geography and Geology, 3, 258-260.

[78] Pourkermani, M. and Arian, M. (1997) Salt Domes of Central Iran. Journal of Humanities, 3, 29-41.

[79] Arian, M., Pourkermani, M., Sistanipour, A. and Noroozpour, H. (2011) Kinematic Significance of Fold- and FaultRelated Fracture Systems in the Rafsanjan's Northeast Highlands (Central Iran). Journal of Basic and Applied Scientific Research, 1, 3398-3406.

[80] Arian, M., Pourkermani, M., Sistanipour, A. and Noroozpour, H. (2011) Seismicity and Fault Segmentation of Bafq- 
Baghin Fault System (Central Iran). Journal of Applied Environmental and Biological Sciences, 1, 382-396.

[81] Mosavi, E.J., Arian, M., Ghorashi, M. and Nazemi, M. (2012) Measurements of Geomorphic Indices in Tabas Area. Journal of the Earth, 7, 213-225.

[82] Arian, M. (2010) Earthquake-Fault Hazard Investigations in the Kerman Quadrangle. Journal of Sciences, 19, $176-182$.

[83] Brönnimann, P., Zaninetti, L., Bozorgnia, F., Dashti, G.R. and Moshtaghian, A. (1971) Lithostratigraphy and Foraminifera of the Upper Triassic Naiband Formation, Iran. Revue de Micropaléontologie, 14, 7-16.

[84] Bull, W.B. (2007) Tectonic Geomorphology of Mountains: A New Approach to Paleoseismology. Blackwell, Malden. http://dx.doi.org/10.1002/9780470692318

[85] Hack, J.T. (1973) Stream-Profiles Analysis and Stream-Gradient Index. Journal of Research of the U.S. Geological Survey, 1, 421-429. 